\title{
Publisher Correction: Parenthood and risk of hip fracture: a 10-year follow-up prospective study of middle-aged women and men in China
}

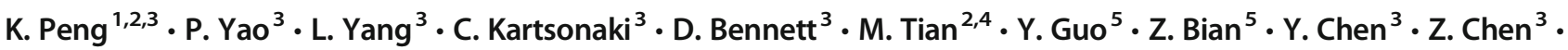 \\ M. Woodward ${ }^{2,6,7} \cdot$ R. Ivers ${ }^{1,2,8} \cdot$ R. Clarke $^{3}$
}

Published online: 11 February 2020

(C) The Author(s) 2020

Publisher Correction: Osteoporosis International (2019)

https://doi.org/10.1007/s00198-019-05185-2

The original version of this article, published on 25 November 2019 , unfortunately contained a mistake.

The Open Access license, which previously read:

Open Access This article is distributed under the terms of the Creative Commons Attribution-NonCommercial 4.0 International License (http://creativecommons.org/licenses/ by-nc/4.0/), which permits any noncommercial use, distribution, and reproduction in any medium, provided you give appropriate credit to the original author(s) and the source,

The online version of the original article can be found at https://oi.org/ $10.1007 / \mathrm{s} 00198-019-05185-2$

R. Clarke

robert.clarke@ndph.ox.ac.uk

1 School of Public Health, The University of Sydney, Sydney, Australia

2 The George Institute for Global Health, UNSW, Sydney, Australia

3 Clinical Trial Service Unit and Epidemiological Studies Unit, Big Data Institute, University of Oxford, Old Road Campus, Oxford OX3 7LF, UK

4 The George Institute for Global Health at Peking University Health Science Center, Beijing, China

5 Chinese Academy of Medical Sciences, Beijing, China

6 The George Institute for Global Health, Oxford University, Oxford, UK

7 Department of Epidemiology, Johns Hopkins University, Baltimore, MD, USA

8 School of Public Health and Community Medicine, UNSW, Sydney, Australia provide a link to the Creative Commons license, and indicate if changes were made.

Should read:

Open Access This article is licensed under a Creative Commons Attribution 4.0 International License, which permits use, sharing, adaptation, distribution, and reproduction in any medium or format, as long as you give appropriate credit to the original author(s) and the source, provide a link to the Creative Commons license, and indicate if changes were made. The images or other third party material in this article is included in the article's Creative Commons license, unless indicated otherwise in a credit line to the material. If material is not included in the article's Creative Commons license and your intended use is not permitted by statutory regulation or exceeds the permitted use, you will need to obtain permission directly from the copyright holder. To view a copy of this license, visit http://creativecommons.org/licenses/ by/4.0\%.

The original article has been corrected. 